\title{
The Contributon of Students' Motivation and Sentence Stucture Toward Writing Skill
}

\author{
Andhika Oktafatria Prasetya, Muh. Asrori, Dewi Sri Wahyuni \\ English Education Department \\ Teacher Training and Education Faculty \\ Sebelas Maret University of Surakarta
}

Email : andhika.prasetya92@gmail.com

\begin{abstract}
This research aimed to find out the correlation between: (1) studentse motivation and writing skill; (2) sentence structure and writing skill; and (3) students $^{\text {ee }}$ motivation and sentence structures simultaneously to writing skill. This study used a correlational method with cluster random sample of 39 students of the eleventh grade of SMK N in Surakarta. The researcher used questionnaire, objective tests and essay test as the instruments to collect the data. Single and Multiple Linear Regression and Correlation were used to analyze the data. The research findings show that: (1) there is positive correlation between students"e motivation and writing skill, in which students"e motivation brings $17.63 \%$ effective contribution to writing skill; (2) there is positive correlation between sentence structure and writing skill, in which sentence structure brings $57.05 \%$ effective contribution to writing skill; and (3) there is positive correlation between students ${ }^{\text {ee }}$ motivation and sentence structures simultaneously to writing skill, in which studentse motivation and sentence structure simultaneously bring $74.68 \%$ contribution to writing skill.
\end{abstract}

Keywords: contribution, students" motivation, sentence structure, writing skill

\section{INTRODUCTION}

Writing has become a basic activity for students in vocational school. They have to write paper, article, book report, and other kinds of writing. Writing skill has still to be mastered for students even they had graduated from school because writing skill is needed in their environment. They have to write Curriculum Vitae (CV) for application letter to apply their job. Moreover, if they worked in some places, writing skill is also needed to write report, article or to write any other practical tasks.

According to Harris (1993:10), "writing is a process that occurs over period of time, particularly if we take into account the sometimes extended periods of thinking that precede creating an initial draft". Petty and Jansen (1980:362) say that writing is the mental and psychical act of forming letters and words. It means that writing is process of expressing feeling of thinking to arrange word into a sentence, sentence into paragraph and paragraph into a convention of written from.

Boice (in Murray and Moore, 2006:7) states that, writing is not just influenced by what we know and what we have discovered about a particular phenomenon, it is also influenced by what we feel, and more particularly, what we feel about ourselves. Writing is influenced by many factors including what we 
discover, feel and think about our environment or ourselves.

Based on explanation above, it can be concluded that writing is process of forming meaningful sequence from symbols into a written form which has certain language meaning.

The studentse writing skill can be contributed by many factors such as teacher, students, curriculum, teaching methods, class condition and many other factors. Those factors can be divided into two categories, linguistic factor and nonlinguistic factor. Non-linguistic factors include motivation, attitude, class

condition, teaching method and curriculum. Linguistic factors include vocabulary, sentence structure and grammar.

Motivation is one of non-linguistic factors that contribute to students ${ }^{\text {ee }}$ learning writing. According to Brophy (1998:3), motivation is a theoretical construct used to explain the initiation, direction, intensity, and persistence of behavior,

especially goal-directed behavior. Motivation in a classroom context is used to explain the degree of which students invest their attention and effort in teaching and learning process.

Elliot, Kratochwill, Cook and Travers (2000:332) state, "Motivation is defined as an internal state that arouses us to action, pushes us in particular directions, and keeps us engaged in certain activities". In addition, Sinclair (in Towndrow, Koh, and Soon, 2008: 37) states that motivation is what moves us to do something that involves energy and drive to learn, work effectively, and achieve potential. Motivation is a state of cognitive arousal which provokes a decision to act that can make people to achieve their goal (Wiliam and Burden, in
Harmer, 2007:98). It means that the strength of motivation will depend on how much value of the individual places on the outcomes of their wishes to achieve their goal.

According to Brown (2007:170) there are two types of motivation from different point of view. The first type is instrumental and integrative and the second type is intrinsic and extrinsic motivation. Brown (1994:153), states that instrumental motivation refers to motivation to acquire a language as a means for attaining instrumental goal. Besides the instrumental motivation, there is one another type of motivation that is integrative motivation. Brown (1994:154) says integrative motivation describes learner who wished to integrate themselves into the culture of the second language group and become a part of the society. From those theories, it can be seen that integrative motivation focus is more on language culture of society than instrumental motivation focuses on purpose of learning language.

From those explanations the writer concludes that motivation is arousal, impulse, emotion or desire that drives people to moves into particular action in order to achieve their goal.

In teaching and learning activity, the concept of studentse motivation is used to explain the degree of students that have a high and low motivation. According to Sun (2010:1), the more motivation they may have, the more effort they tend to put into learning the language. From those theories, it shows that highly motivated students usually have high spirit to reach their goal, learn and practice more than low motivated students. The teacher must make students highly motivated to learn with telling some 
funny and motivated stories, variation of teaching and learning, or put game in every process of teaching and learning in class.

The linguistic factor that can contribute to students ${ }^{\text {ee }}$ writing skill is sentence structure. The understanding of sentence structure will lead students to make effective sentences in expressing ideas and feelings. Widiarso (2006:15) says that the absence of sentence structure understanding will lead students to make grammatical mistakes in writing a text. There are some experts who define the term of sentence structure.

According to Oshima \& Hogue (2006: 164), sentence is a group of words used to communicate ideas. Sentence is the largest unit of grammatical organization within which parts of speech (e.g. nouns, verbs, and adverbs) and grammatical classes (e.g. word, phrase, and clause) are said to function (Richards \& Schmidt, 2010: 522). In addition Ur, (1996:79) says that sentence is a set of words standing or their own as sense unit, its conclusion marked by a full stop, question mark or exclamation mark. It can be concluded that sentence is the group of words which stand as sense unit that involves in parts of speech and grammatical classes to communicate the ideas.

People may get confused with the term of structure and grammar. According to Richards \& Schmidt (2010:251), grammar is a description of the structure of a language and the way in which linguistic units such as words and phrases are combined to produce sentences in the language. But, Ur, (1996:79) says that a specific instance of grammar is usually called a structure. In this study, grammar refers to sentence structures that are limited to construct and organize sentences. Then, McCrimson (1963:402) says that sentence can be studied in the term of two kinds unit: form units, which show inflectional changes in word, and function units, which show how words are related in a sentence, chiefly into word order.

Based on the statements above, it can be concluded that the term of sentence structure is linguistic rules which use to construct a correct form sentence. With the correct form of sentence, we can express our idea clearly

From those explanations, the aims of the research is to know whether: (1) there is a contribution of students ${ }^{\text {ee }}$ motivation to writing skill of the eleventh grade students of SMK N in Surakarta; (2) there is a contribution of sentence structure to writing skill of the eleventh grade students of SMK $N$ in Surakarta in the academic year 2013/2014; (3) there is a contribution of students ${ }^{\text {ee }}$ motivation, sentence structure simultaneously to writing skill of the eleventh grade students of SMK N in Surakarta.

\section{RESEARCH METHODS}

In conducting the research, the writer used the quantitative correlational method. According to Nunan (1992:3), quantitative research is obstructive and controlled, objective, generalisable, outcome oriented, and assume that existence of facts which are somehow external to and independent of the observer or researcher. In addition, Singh (2007:16) says that correlation is one of the most widely used measures of association between two or more variables. This research has two kinds of variables, predictor variable or independent variable and response variable or dependent variable. The predictor or the independent 
variables in this research are students ${ }^{\text {ee }}$ motivation $\left(\mathrm{X}_{1}\right)$ and sentence structure $\left(\mathrm{X}_{2}\right)$. The response variable or dependent variable is writing skill $(\mathrm{Y})$.

The research had 39 studentrespondents which were selected randomly from the eleventh grade of SMK N in Surakarta in the academic year 2013-2014. The tests were administered at SMK N in Surakarta over three days. Researcher used questionnaire to collect the students ${ }^{\text {ee }}$ motivation data and test to measure sentence structure and writing skill. The tests were the objective test in the form of multiple choices test for sentence structure and an essay test for writing skill. Before doing the tests, the researcher explained about the test instruction and the purpose of this research. In the first day of getting the data, the researcher was giving them the questionnaire about studentse motivation. They take 45 minutes to fulfill the questionnaire. After fulfilling the questionnaire, the next day students were asked to do the sentence structure test for 60 minutes. In the third day, the researcher gave a test of writing for 60 minutes.

\section{RESEARCH FINDINGS AND DISCUSSIONS}

In this part of the research, the correlation between students ${ }^{\text {ee }}$ motivation and their writing skill, the correlation between sentence structure and their writing skill and the correlation between students $^{\text {ee }}$ motivation and sentence structure simultaneously, toward writing skill were presented.

The result showed that participant of students ${ }^{\text {ee }}$ motivation, sentence structure, and writing skill score are normally distributed. So, the tests of three variables in this research were valid and there were no diffraction especially in small sample.
The result of regression is linear and significant. So, the rise and the fall of writing skill are followed linearly by the rise and the fall of students ${ }^{\text {ee }}$ motivation and sentence structure.

The first finding came from the correlation between students ${ }^{\text {ee }}$ motivation and writing skill. Based on the computation of linearity and significance of regression test of students ${ }^{\text {ee }}$ motivation $\left(\mathrm{X}_{1}\right)$ and writing skill $(\mathrm{Y})$, the result is linear and significant. The result shows that the linearity of students ${ }^{\text {ee }}$ motivation $\left(\mathrm{X}_{1}\right)$ and writing skill $(\mathrm{Y}),\left(\mathrm{F}_{\mathrm{O}}\right)$ is 1.7736. To know whether or not students ${ }^{\text {ee }}$ motivation $\left(\mathrm{X}_{1}\right)$ and writing skill $(\mathrm{Y})$, are in linear regression, $\mathrm{F}_{\mathrm{O}}$ must be compared to $\mathrm{F}$ table. The value of $\mathrm{F}$ table $\mathrm{N}=39$ with the degree of freedom (df) 18 and 19 at the level of significance $\alpha=0.05$ is 2.16 . $F_{0}$ is lower than $\mathrm{Ft}_{\mathrm{t}}$ or $\mathrm{F}_{\mathrm{O}}(1.7736)<(2.16)$. It can be concluded that the regression is linear. While, the computation showed the significance test of students ${ }^{\text {ee }}$ motivation (X1) and writing Skill (Y) $\alpha=0.05$ for, df 1 and $37\left(\mathrm{~F}_{\mathrm{O}}\right)$ is 18.249 . It must be compared to $\mathrm{F}$ table. The table shows that $\mathrm{F}$ for $\alpha=$ 0.05 , df 1 and 37 is $\left(F_{t}\right)=4.08$. $F_{O}$ is greater than $\mathrm{F}_{t}$ or $\mathrm{F}_{\mathrm{O}}(18.249)>\mathrm{F}_{\mathrm{t}}$ (4.08). It means that the regression is significant.

When examining the simple correlations associated with the regression, the researcher noted that the performance of studentse motivation was related with performance of writing skill $\left(\mathrm{r}_{\mathrm{x}} 1 \mathrm{y}=\right.$ $0.3303)$. Then, the value is compared to $r$ table at significance level $\alpha=0.05$ for $\mathrm{N}=$ 39. It is found that $r$ table is $=0.316$. It can be seen that $r_{x} 1 y$ is greater than $r$ table. It means that Ho is rejected and there is positive correlation between students ${ }^{\text {ee }}$ motivation $\left(\mathrm{X}_{1}\right)$ and writing skill (Y).

The coefficient of determination $\left(\mathrm{r}^{2}\right)$ between students ${ }^{\text {ee }}$ motivation $\left(\mathrm{X}_{1}\right)$ and 
writing skill (Y) is 0.3303 . It means that $33.03 \%$ variation of writing skill is contributed by students ${ }^{\text {ee }}$ motivation (X1) and $66.97 \%$ is contributed by other factors.

The second finding came from the correlation between sentence structure and writing skill. Based on the computation of linearity and significance of regression test the result shows that the linearity sentence structure $\left(\mathrm{X}_{2}\right)$ and writing skill $(\mathrm{Y}),\left(\mathrm{F}_{\mathrm{O}}\right)$ is 1.9936. To know whether or not sentence structure $\left(\mathrm{X}_{2}\right)$ and writing skill $(\mathrm{Y})$ are in linear regression, $\mathrm{F}_{\mathrm{O}}$ must be compared to $\mathrm{F}$ table. The value of $\mathrm{F}$ table $\mathrm{N}=39$ with the degree of freedom (df) 11 and 26 at the level of significance $\alpha=0.05$ is 2.22 . $F_{O}$ is lower than $\mathrm{F}_{t}$ or $\mathrm{F}_{\mathrm{O}}(1.9936)<(2.22)$. It can be concluded that the regression is

\section{linear.}

The computation showed that the significance test of sentence structure $\left(\mathrm{X}_{2}\right)$ and writing skill (Y) $\alpha=0.05$ for, df 1 and $37\left(\mathrm{~F}_{\mathrm{O}}\right)$ is 73.973 . It must be compared to $\mathrm{F}$ table. The table shows that $\mathrm{F}$ for $\alpha=0.05$, df 1 and 37 is $\left(F_{t}\right)=4.08 . F_{O}$ is greater than $F_{t}$ or $F_{O}(73.973)>F_{t}(4.08)$. It means that the regression is significant.

The result of correlation computation using Pearson Product Moment Formula of structure $\left(\mathrm{X}_{2}\right)$ and writing skill (Y) shows that the coefficient of correlation is $\left(r_{x} 1 y\right)=0.816$. Then the value is compared to $r$ table at significance level $\alpha=0.05$ for $\mathrm{N}=39$. It is found that $\mathrm{r}$ table is $=0.316$. It can be seen that $r_{x} 2 y$ is greater than $r$ table. It means that $\mathrm{Ho}$ is rejected and there is positive correlation between sentence structure $\left(\mathrm{X}_{2}\right)$ and writing skill (Y).

The coefficient of determination $\left(r^{2}\right)$ between sentence structures $\left(X_{2}\right)$ and writing skill $(\mathrm{Y})$ is 0.3303 . It means that $66.66 \%$ variation of writing skill is contributed by sentence structure (X2) and $33.34 \%$ is contributed by other factors.

The third finding came from the correlation between students ${ }^{\text {ee }}$ motivation and sentence structure simultaneously to writing skill. The technique used here is multiple linear regressions .From the computation of multiple regressions, it was found that the coefficient of a1, a2, and ao are $0.0726,0.674$, and 45.383. Therefore, the multiple linear regression equitation of writing skill (Y) on students ${ }^{\text {ee }}$ motivation $\left(\mathrm{X}_{1}\right)$ and sentence structure $\left(\mathrm{X}_{2}\right)$ becomes: $\mathrm{Y}=45.38+0.726 \mathrm{X}_{1}+0.674 \mathrm{X}_{2}$.

The testing of significance of the correlation coefficient result for $F_{O}$ is 53.105. This value is compared to $\mathrm{F}$ table at $5 \%$ significant level degree of freedom (df) $2: 36$ is 3.23 . It is obvious that $F_{O}$ is greater than $\mathrm{F}$ table $(53.105>3.23)$. It means that $F_{O}$ is significant. So, it can be concluded that the regression equation is also significant.

From the multiple linear regression analysis of students ${ }^{\text {ee }}$ motivation $\left(\mathrm{X}_{1}\right)$, and sentence structure $\left(\mathrm{X}_{2}\right)$ with writing skill $(\mathrm{Y})$, the writer finds that the coefficient of correlation $\left(R_{y} 12\right)$ is 0.86 . This value then is tested by using significant test which the result in $\mathrm{F}_{\mathrm{O}}=53.105$ which is greater than $F$ table 3.23 with degree of freedom (df) 2: 36 and at the level of significance $\alpha=0.05$. It means that $\mathrm{R}$ is significant. It can also be meant that $\mathrm{Ho}$ is rejected and $\mathrm{Ha}$ is accepted. So, it can be concluded that there is a positive correlation between students ${ }^{\text {ce }}$ motivation $\left(\mathrm{X}_{1}\right)$ and sentence structure (X2) simultaneously and writing skill (Y).

The computation of regression is aimed to predict the correlation between each variable and to identify which one of the two variables that has more contribution than the other variable. Based on the computation it is obtained that the 
contribution of students ${ }^{\text {ee }}$ motivation (X1) is $23.61 \%$ as the relative contribution and $17.63 \%$ as the effective contribution. While the contribution of sentence structure $\left(\mathrm{X}_{2}\right)$ is $76.39 \%$ as the relative contribution and $57.05 \%$ as the effective contribution.

\section{DISCUSSION}

For the first aim, the researcher was interested in determining whether there is a correlation between students ${ }^{\text {ee }}$ motivation to writing skill. Based on the finding, studentse motivation gives contribution to students ${ }^{\text {ee }}$ writing skill. The result confirmed that there is a positive significant correlation $\left(\mathrm{t}_{\mathrm{o}}=4.27194>\mathrm{t}_{\mathrm{t}}=\right.$ 1.70) between students motivation and writing skill. In teaching and learning activity, the concept of students ${ }^{\text {ee }}$ motivation is used to explain the degree of students that have a high and low motivation. Students who have high motivation are willing to learn more than others. Those are in line with Sun (2010:1), who says the more motivation they may have, the more effort they tend to put into learning the language. It makes students ${ }^{\text {ee }}$ motivation has important rules in developing students ability in learning writing. Then, Ghavania et all (2011: 1116), et al say that the learning motivation aspect can motivate students to involve and enhance learning effectiveness. It shows that motivation is included as one factor that contributes to students $^{\text {ee }}$ writing skill. Motivation can increase the student ability in learning writing because motivation can make student desire and have enthusiasm to learn about anything. Based on the computation, students ${ }^{\text {ee }}$ motivation gives contribution to writing skills about $33.03 \%$.
The second aim was finding out the correlation between sentence structure and writing skill. Sentence structure is one of linguistic factors that can contribute to students ${ }^{\text {ee }}$ writing skill. The understanding of sentence structure will lead students to make effective sentences in expressing ideas and feelings. It makes sentence structure become important component of writing. If students can make a good arrangement of sentence structure they will make a good writing too. Those are in line with Widiarso (2006:15), who says that the absence of sentence structure understanding will lead students to make grammatical mistakes in writing a text. Based on the computation, it showed that $66.66 \%$ variance of writing skill was determined by sentence structure.

The last result said that there is a positive correlation between students ${ }^{\text {ee }}$ motivation and sentence structure simultaneously to writing skill. According to Boice (in Murray and Moore, 2006:7), writing is not just influenced by what we know and what we have discovered about a particular phenomenon, it is also influenced by what we feel, and more particularly, what we feel about ourselves. Then, Nunan (1989:36) says that, the aspect of writing is content, format,

sentence structure, vocabulary, punctuation, spelling and letter formation. With mastering sentence structure will help students to have awareness to construct a good writing. The students ${ }^{\text {ee }}$ awareness can make a big impact in process of creating good writing. They will have more attention in detail of writing from word structure to sentence structure until the coherence and mechanic of the paragraph of their writing.

The impulse of students ${ }^{\text {ee }}$ motivation makes them willing to learn 
and explore more specifically about writing. If they were motivated, they will ask anything about writing in their teacher. They will be curious how about to construct a good writing, and how they can learn to do it.

Based on the data gathered, it can be stated that both studentse motivation and sentence structure appeared to be significant predictors for their writing skill.

\section{CONCLUSION AND SUGGESTION}

The data analysis shows that there

is a positive correlation between students ${ }^{\text {ee }}$ motivation and writing skill, there is a positive correlation between sentence structure and writing skill, and there is a positive correlation between students ${ }^{\text {ee }}$ motivation and sentence structure simultaneously, and writing skill of the eleventh students of one of SMK $\mathrm{N}$ in Surakarta. Judging by quantity, the

sentence structure brings more contribution $(66.66 \%$ to writing skill than the contribution of students ${ }^{\text {ee }}$ motivation to writing skill (33.03\%). The students ${ }^{\text {ee }}$ motivation and sentence structure

simultaneously bring the highest contribution to writing skill (74.68\%). Therefore, the two variables cannot be ignored in the effort to improve the student"s writing skill.

It is suggested for the teachers, in order to increase students ${ }^{\text {ee }}$ writing ability, they teacher should give them motivation to learn. The teacher can tell motivating stories to make students have high motivation to learn writing. Moreover, to make students aware about their writing mistakes that they usually make in writing, the teacher should give easy task with many grammatical errors and ask students to identify the errors.
For students, they must have high motivation to learn something because if they have high motivation, they will be encouraged themselves to learn about anything that they want. Moreover, students must have awareness about their grammatical or structure errors when they made in the process of writing. With their awareness, they can more concern about their mistake and error so they correct it easily to make the good one of writing.

\section{BIBLIOGRAPHY}

Brophy, J. 1998. Motivating Students to Learn. USA: McGraw Hill.

Brown, H.D. 1994. Principles of Language Learning and Teaching. USA: Prince Hall Inc.

Brown, H.D. 2007. Principles of Language Learning and Teaching $5^{\text {th }}$ Edition. USA: Pearson Education Inc.

Bryne, D. 1997. Teaching Writing Skills. Malaysia: Longman.

Elliot, Stephen N., Kratochwil, T. R., Cook, J.L., \& Travers, J.F. 2000. Educational Psychology: Effective Teaching, Effective Learning Third Edition.

USA: The McGraw-Hill

Companies, Inc.

Fulwiler, T. 2002. College Writing A Personal Approach to Academic Writing $3^{\text {rd }}$ Edition. USA: Boynton/Cook Publisher Inc.

Ghavamnia, M., Kassian, Z., \& Dabaghi, A. (2011). The Relationship between Language Learning Startegies, Language Learning Beliefs, Motivation and Proficiency: A Study of EFL 
Learners in Iran. Journal of

Language Teaching and Research. 2 (5). 1156-1161.

Retrieved 6 August 2014 from doi:10.4304/jltr.1.6.889-892

Harmer, J. 2007. The Practice of English Language Teaching $4^{\text {th }}$ Edition. Education.

England: Pearson

Haris, J. 1993. Introducing Writing.

London: Penguin Group.

Hughes, R. 2005. English in Speech and Writing Investigating Language and Literature.

USA:

Routledge.

McCrimson, J. M. 1963. Writing with A Purpose. USA: Houghton Mifflin Company.

Murray, R. \& Moore, S. 2006. The Handbook of Academic Writing A Fresh Approach. USA: McGraw Hill.

Nation, I. S. P. 2009. Teaching ESL/EFL Reading and Writing. UK: Routledge.

Nunan, David. 1989. Designing Test for the Communicative Classroom. United Kindom: Cambridge University Press.

Nunan, David. 1992. Research Methods in Language Teaching. USA: Cambridge University Press.
Oshima, A. \& Hogue, A. 2006. Writing Academic English. USA: Pearson Education.

Petty, T. W. \& Jensen, J. M. 1980. Developing Children Language. USA: Allyn \& Bacon Inc.

Richards, J., C. \& Schmidt, R. 2010. Longman Dictionary of Language Teaching and Applied Linguistic $4^{\text {th }}$ Edition. Malaysia: Pearson Education.

Singh, Kultar. 2007. Quantitative Social Research Methods. New Delhi: Sage Publications.

Sun, Zhuomin. (2010). Language Teaching Material and Learner Motivation.

Journal of Language Teaching and Research. 1 (6). 889-892. Retrieved 6 August 2014, from doi:10.4304/jltr.1.6.889-892

Towndrow, P.A., Caroline, K. \& Soon, T., H. 2008. Motivation and Practice for the Classroom. Sense Publishers.

Ur, Penny. 1996. A Course in Language Teaching Practice and Theory. UK: Cambridge University Press.

Widiarso. 2006. Kiat Menulis Dalam Bahasa Inggris. Yogyakarta: Penerbit Kanisius. 